\title{
Akciğer, meme ve kolon kanserli hastalarda oksidatif stres parametrelerinin değişimi
}

Variation of oxidative stress parameters in patients with lung, breast and colon

\section{cancer}

\author{
Ömer Faruk Özer ${ }^{(\mathbb{D})}$, Eray Metin Güler ${ }^{1} \mathbb{D}$, Şahabettin Selek ${ }^{1} \mathbb{D}$, Ganime Çoban² ${ }^{\mathbb{D}}$, Hacı Mehmet Türk ${ }^{(\mathbb{D})}$, Abdurrahim \\ Koçyiğiț (D)
}

1 Bezmialem Vakıf Üniversitesi Tıp Fakültesi, Tıbbi Biyokimya Anabilim Dalı, İstanbul, Türkiye

2 Bezmialem Vakıf Üniversitesi Tıp Fakültesi, Tıbbi Patoloji Anabilim Dalı, İstanbul, Türkiye

${ }^{3}$ Bezmialem Vakıf Üniversitesi Tıp Fakültesi, Dahiliye Anabilim Dalı Tıbbi Onkoloji Bilim Dalı, İstanbul, Türkiye

\section{Öz.}

Amaç: Kanser dünyada çok yaygın ölümcül bir hastalıktır. Kanser oluşumunda birçok nedenden dolayı hücresel düzeyde meydana gelen oksidatif stresin etkili olduğu düşünülmektedir. Bu çalışmada akciğer, meme ve kolon kanserlerinde oksidatif durumun kanser türlerindeki değişiminin araştıııması amaçlandı.

Materyal ve Metot: Medikal Onkoloji bölümünde tedavileri süren 44 akciğer kanseri, 37 meme kanseri, 20 kolon kanseri hastası çalışmaya dahil edildi. Çalışmaya katılan hastaların tamamı histopatolojik olarak tanısı kesinleștirilirmiş hastalardı. Hastaların Total Antioksidan Seviye (TAS), Total Oksidan Seviye (TOS) ile Katalaz (CAT) ve Myeloperoksidaz (MPO) enzim aktiviteleri otoanalizörde fotometrik yöntemle ölçülüp, 43 sağıklı gönüllü ile karşılaştırıldı.

Bulgular: TOS seviyeleri kontrol grubuna göre meme kanserinde anlamlı olarak yüksek bulunurken $(p<0.002)$, diğer kanser gruplarında yüksek olmakla birlikte anlamlı fark bulunmadı. Oksidatif Stres İndeksi (OSi) ise her üç kanser türünde de kontrol grubuna göre anlamlı derecede düşük bulundu $(p<0.001)$. TAS, CAT ve MPO aktiviteleri her üç kanser tipinde de kontrol grubuna göre anlamlı derecede yüksek idi. ( $p<0.001)$.

Sonuç: Çalışmada, kanserde oksidatif stresin artığı ancak, artmış oksidatif stresin antioksidan savunma sistemini indüklemesi nedeni ile OSI seviyesini düşürmüş olabileceği sonucuna varıldı.

Anahtar Kelimeler: Oksidatif stres, Akciğer kanseri, Meme kanseri, Kolon kanseri

\section{Abstract}

Background: Cancer is a very common deadly disease in the world. In the cancer formation oxidative stress on the cellular level is thought to be effective for many reasons. The aim of this study was to investigate the changes in oxidative status in cancer types in lung, breast and colon cancers.

Methods: Forty-four lung cancer patients, 37 breast cancer patients and 20 colon cancer patients in the medical oncology department were included in the study. All patients were histopathologically diagnosed. Total Antioxidant Levels (TAS), Total Oxidant Levels (TOS) and Catalase (CAT) and Myeloperoxidase (MPO) enzyme activities were measured by photometric method in autoanalyser and compared with 43 healthy volunteers.

Results: TOS was significantly higher in all cancer types than control group, but not statistically significant, but significantly higher in breast cancer $(\mathrm{p}<0.002)$. Oxidative Stress Index (OSI) were found to be significantly lower in all three types of cancer than in the control group $(p<0.001)$. TAS, CAT and MPO values were significantly higher in all three types of cancer than in the control group ( $p<0.001)$.

Conclusion: In the study, it was concluded that oxidative stress increased in cancer, but increased oxidative stress may decrease OSI level due to induction of antioxidant defense system.

Keywords: Oxidative stress, Lung cancer, Breast cancer, Colon cancer

\section{Sorumlu Yazar I Corresponding Author}

Dr. Ömer Faruk ÖZER

Bezmialem Vakıf Üniversitesi Tıp Fakültesi Tıbbi Biyokimya Anabilim Dalı, Adnan Menderes Bulvarı, Vatan Cad. İstanbul, Türkiye

Tel: +90 5052797212

e-mail: omerfaruk2005@yaho.com

Geliş tarihi / Received: 11.06 .2019

Kabul tarihi / Accepted: 24.07.2019

Bu çalıșma: "1st International Congress on Cancer and lon Channels, 21 - 23 September 2017, Şanlıurfa, Türkiye" kongresinde poster olarak sunulmuştur.

DOI: 10.35440/hutfd.576016 


\section{Giriş}

Kanser dünyada ölüm sebeplerinin başında gelen ve normal vücut hücrelerinin kontrolsüz olarak çoğalmasıyla gelişen bir hastalıktır. Klonal yayılma ile çevresindeki dokulara ve kan veya lenf yoluyla da bütün vücuda yayılabilir. En çok rastlanan ölümcül kanser çeşitleri akciğer, meme ve kolon kanserleridir $(1,2)$.

Kanser gelişimi ile birlikte hücre içinde önemli değişiklikler meydana gelmektedir. Başlangıç safhasında kanser, gen ekspresyonunu düzenleyen epigenom, kromozom ve DNA hasarı ile kendini gösterir. Başlangıç safhasını uzun bir süreç takip eder. İnflamasyonla birlikte genomik olarak kararsız hücrelerin büyüdüğü görülür. İlerleme safhasında ise hücreler çoğalırken, genomlarına daha fazla zarar vererek kötü huylu tümöre dönüşür $(3,4)$.

Serbest radikaller, dış yörüngesinde çift oluşturmamış bir elektron içeren reaktif bileşiklerdir. Diğer moleküllere elektron verebildiklerinden ya da onlardan elektron alabildiklerinden vücutta indirgeyici veya yükseltgeyici olarak davranılar. Serbest radikaller oksijen ve nitrojen kaynaklı olabilirler. Bunlardan reaktif oksijen türleri (ROS) arasında süperoksit, hidroksil, peroksil, lipit peroksil ve alkoksil radikalleri sayılabilir. Reaktif nitrojen türlerini ise nitrik oksit ve nitrojen dioksit oluşturur. Serbest radikaller endojen ve eksojen kaynaklar tarafından meydana getirilir (5).

ROS, sürekli olarak hücresel işlemlerin yan ürünleri olarak üretilmektedir. Endojen ROS'un en önemli üretim yeri mitokondridir. Düşük ve orta düzey yoğunlukta ROS hücrelerde enfeksiyöz ajanlara karşı korumada, sinyal iletim yolaklarını düzenlemede ve mitojenik uyarlara karşı yanıtın başlatımasında etkilidir. ROS'un aşırı üretilmesi sonucunda eğer hücreler bu aşırılıkları yeterince yok edemezse hücrelerde "oksidatif stress" adı verilen durum ortaya çıkar (6).

Canlıda serbest radikaller yoğunlukları artığı durumlarda lipitler, proteinler ve nükleik asitler üzerinde yapısal bozukluklara neden olurlar ve bunun sonucunda da kanser, nörodejeneratif hastalıklar ve kardiyovasküler hastalıklar gibi kronik hastalıkların nedeni ve risk faktörü olarak görülmektedirler (7).

Metabolizmasının hızlı olması ve hücresel sinyal mekanizmasının bozulmuş olması nedeniyle, kanser hücreleri yüksek ROS üretimine sahiptir. Yüksek ROS seviyeleri genellikle hücreler için zararlıdır ve kanser hücrelerinin redoks durumu normal hücrelerinkinden farklıdır. Kanser hücreleri, bu nedenle ROS seviyelerini, düşük bir sitostatik seviyenin üstünde, ancak sitotoksik olacak seviyelerin altında, orta derecede yüksek bir tümörojenik düzeyde tutarlar (8). Tümörojenik hücrelerin; proliferasyon, hayatta kalma ve metabolik adaptasyonu devam ettirebilmek için (yani, redoks biyolojisi) normalden yüksek seviyelerde ROS ürettiği bir model düşünülmektedir. Aynı zamanda, kanser hücreleri, hücre ölümünü (yani oksidatif stres) indükleyebilecek seviyelerde ROS birikmesini önlemek için normalden yüksek seviyede antioksidan aktiviteyi sürdürürler. Kanser olmuş hücredeki oksidatif stres durumu ile normal hücredeki oksidatif stres durumu bu açıdan farklıdır. Ayrıca, oksidatif stresin ve inflamasyonunun artmasının kanser riski ile ilişkili olduğu da iyi bilinmektedir. Bu açıdan çalışmamızda akciğer, meme ve kolon kanseri hastalarının serumlarında oksidatif stres parametrelerinin sağlıklı gönüllülere göre değişimini ortaya koymayı amaçladık.

\section{Materyal ve Metot}

Çalışmamıza Aralık 2017 ve Temmuz 2018 tarihleri arasında Medikal Onkoloji polikliniğinde tedavileri devam eden $35-80$ yaş arası 44 akciğer kanseri, 37 meme kanseri, 20 kolon kanseri hastası dahil edildi. Ayrıca 43 sağlıkı gönüllü çalışmaya kontrol grubu olarak dahil edildi. Çalışma için gerekli etik kurul onayı Bezmialem Vakıf Üniversitesi Klinik Araştırmalar Etik Kurulu'ndan alınıp tüm hastalara onam formu onaylatıldı.

Çalışmaya katılan hastaların tamamı histopatolojik olarak tanısı kesinleştirilirmiş ve bir kür kombine kemoterapi (sispaltin, doksorubisin, metotreksat, 5-fluorouracil) almış hastalardı. Bir kür tedavi aldıktan 21 gün sonra hastaların venöz kanları toplandı.

Hem çalışma grubu hem de kontrol grubunda ikincil lipid hastalığı, kardiyovasküler hastalık, böbrek yetmezliği, kronik enfeksiyon ve enflamasyonu ve alkol kullanımı olanlar çalışmaya dahil edilmedi.

Çalışma grubu dışardan tedavi amaçlı antioksidan almayan hastalardan oluşturuldu.

Hastalardan ve kontrol grubundan venöz kanlar ortalama 12 saat açııtan sonra alındı. Kanlar serumları elde edilmek üzere 3000 x g'de 10 dakika santrifüj edildi. Elde edilen serumlar çalışma yapılana kadar $-80^{\circ} \mathrm{C}$ 'de saklandı. Örnekler istenilen sayıya ulaştığı zaman oksidatif stres parametrelerinin düzeyleri analiz edildi.

Total Antioksidan Status (TAS) düzeyleri oto analizörde (Siemens ADVIA 1200) Erel (9) tarafından geliştirilen yöntem kullanılarak ölçüldü. Bu yöntemde TAS düzeyi ölçülürken $\mathrm{Fe}^{2+}$-o-dianisidin kompleksi hidrojen peroksit ile Fenton tipi reaksiyon oluşturarak $\mathrm{OH}$ radikalini oluşturur. $\mathrm{Bu}$ güçlü reaktif oksijen türü indirgenerek düşük pH'da renksiz o-dianisidin molekülüyle reaksiyona girer ve kahverengisarı renkli dianisidil radikalleri oluşur. Dianisidil radikalleri ileri oksidasyon reaksiyonlarına katılarak renk oluşumunu artırır. Ancak örneklerdeki antioksidan bileşikler bu oksidasyon reaksiyonlarını bastırarak renk oluşumunu azaltmaktadır. Bu düşüş otomatik analizörde spektrofotometrik olarak ölçülerek TAS sonuçları belirlendi. Sonuçlar mmol Trolox Equiv/L şeklinde ifade edildi.

Total Oksidan Status (TOS) düzeyleri de Erel (10) tarafından geliştirilen tam otomatik kolorimetrik (Siemens ADVIA 1200) bir yöntemle ölçüldü. Bu yöntemde numunede bulunan oksidanlar ferröz iyon-o-dianisidin kompleksini ferrik 
iyona oksitlerler. Ortamda bulunan gliserol bu reaksiyonu hızlandırarak yaklaşık üç katına çıkarır. Ferrik iyonlar asidik ortamda "xylenol orange" ile renkli bir kompleks oluştururlar. Örnekte bulunan oksidanların miktarıyla orantılı olarak oluşan rengin şiddeti otoanalizörde spektrofotometrik olarak ölçülerek TOS sonuçları elde edildi. Sonuçlar $\mu \mathrm{mol}$ $\mathrm{H}_{2} \mathrm{O}_{2}$ Equiv/L şeklinde ifade edildi.

Oksidatif stres indeksi (OSi) aşağıdaki formüle göre hesaplandı (11) : OSI =TOS/TASx10

Katalaz aktivitesinin ölçümü: Antioksidatif durumun bir göstergesi olan katalaz aktivitesi Aebi ve ark.'nın (12) $\mathrm{H}_{2} \mathrm{O}_{2}$ 'nin parçalanarak azalmasına dayanan spektrofotometrik yöntem ile (Siemens ADVIA 1200) ölçüldü (IU/mL). Myeloperoksidaz (MPO) aktivitesinin ölçümü: Örneklerdeki myeloperoksidaz aktivitesi Krawisz ve arkadaşlarının (13) yöntemi kullanılarak otoanalizörde (Siemens ADVIA 1200) ölçüldü (IU/mL).

\section{İstatistiksel analiz}

Çalışmamızda SPSS 20 (IBM Corp. Armonk, NY, USA) istatistik programı kullanıldı. Verilerin dağılımını belirlemek için Kolmogorov-Smirnov testi uygulandı. Veriler parametrik dağılıma uygun olduğu için tek yönlü varyans analizi (ANOVA) kullanılarak değerlendirildi. Sonuçlar ortalama \pm SD (Standart sapma) şeklinde verildi. $p<0,05$ düzeyi anlamlı olarak kabul edildi.

\section{Bulgular}

Çalışma grubuna ait tüm demografik veriler ve çalışılan parametrelerin düzeyleri Tablo 1 ve 2'de gösterilmiştir. ÇaIışma ve kontrol grubundaki hastalar yaş, vücut kitle indeksi açısından benzerlik gösteriyordu. $(p>0,05)$

Çalışmamıza 43 sağlıklı gönüllü, 44 akciğer kanseri hastası, 37 meme kanseri hastası, 20 kolon kanseri hastası dahil edildi. TAS, Katalaz ve MPO düzeyleri her üç kanser tipinde de kontrol grubuna göre anlamlı derecede yüksek bulundu $(p<0,001)$. Kontrol grubu, akciğer kanseri, meme kanseri ve kolon kanseri TAS değerleri sırasıyla $1,17 \pm 0,15 ; 2,92 \pm 0,12 ; 2,98 \pm 0,12 ; 3,021 \pm 0,16$ (mmol TroloxEquiv/L) olarak bulundu. TOS düzeyi meme kanserinde $6,40 \pm 1,42 \mu \mathrm{mol} \mathrm{H}_{2} \mathrm{O}_{2}$ Equiv/L, kontrol grubunda ise $5,21 \pm 1,67 \mu \mathrm{mol} \mathrm{H}_{2} \mathrm{O}_{2}$ Equiv/L idi ve aralarında anlamlı derecede fark vardı $(p<0,002)$. Ancak akciğer ve kolon kanserlerinde de TOS düzeyleri kontrol grubundan yüksek olmasına rağmen gruplar arası istatistiksel olarak anlamlı fark bulunamadi ( $p>0,05)$ (Tablo 2).

Oksidatif stres indeksi (OSi) her üç kanser tipinde de kontrol grubuna göre anlamlı derecede düşük bulundu $(p<0,001)$ (Şekil 1).

\section{Tartışma}

Karsinogenez DNA hasarlanması sonucu oluşan mutasyonlardan kaynaklanır. DNA hasarının ana sebebi serbest radikallerin sayısını arttıran oksidatif strestir. Reaktif oksijen türleri (ROS) vücutta oksidatif hasara neden olan en önemli serbest radikallerdir $(14,15)$. Literatürde oksidan, antioksidan moleküller ve farklı insan kanseri türlerinde enzimler hakkında rapor edilen veriler tartışmalıdır (16-19). En yaygın görülen üç kanser türünde yaptığımız çalışmada meme kanseri hastalarında anlamlı düzeyde; akciğer ve kolon kanseri hastalarında ise istatistiksel olarak anlamlı olmasa da kontrol grubuna göre total oksidan durumda orta düzede bir artış bulduk. Buna mukabil tüm hasta gruplarında total antioksidan durum ve katalaz düzeyleri kontrol grubuna göre anlamlı düzeyde artmıştı.

Tablo 1. Çalışmamıza dahil edilen bireylerin demografik özellikleri

\begin{tabular}{|c|c|c|c|c|c|}
\hline & Kontrol Grubu (n:43) & Akciğer $\mathrm{Ca}(\mathrm{n}: 44)$ & Meme Ca (n:37) & Kolon Ca (n:20) & $p$ \\
\hline \multicolumn{6}{|l|}{ Cinsiyet } \\
\hline Erkek/ Kadın & $23 / 20$ & $42 / 2$ & $5 / 32$ & $4 / 16$ & $>0,05$ \\
\hline $\begin{array}{l}\text { Yaş } \\
\text { Ortalaması(yıl) }\end{array}$ & $59 \pm 7,3$ & $60,4 \pm 8,4$ & $52,4 \pm 8,9$ & $62,7 \pm 12,3$ & $>0,05$ \\
\hline \multicolumn{6}{|l|}{ Boy ortalaması(m) } \\
\hline & $1,61 \pm 0,07$ & $1,64 \pm 0,08$ & $1,60 \pm 0,09$ & $1,58 \pm 0,10$ & $>0,05$ \\
\hline \multicolumn{6}{|l|}{ Kilo ortalaması(kg) } \\
\hline & $69,9 \pm 13,5$ & $66,0 \pm 14,2$ & $77,9 \pm 16,2$ & $69,4 \pm 12,4$ & $>0,05$ \\
\hline \multicolumn{6}{|l|}{ Vücut Kitle İndeksi } \\
\hline & $27,3 \pm 5,7$ & $24,5 \pm 4,6$ & $30,2 \pm 6,1$ & $27,7 \pm 3,7$ & $>0,05$ \\
\hline \multicolumn{6}{|l|}{ Sigara kullanımı } \\
\hline Evet/ Hayır & $29 / 14$ & $41 / 3$ & $14 / 23$ & $11 / 9$ & $>0,05$ \\
\hline
\end{tabular}

Sonuçlar ortalama \pm standart sapma şeklinde ifade edilmiştir. Kategorik verilerin analizinde Ki kare testi, sayısal verilerin analizinde Kruskal-Wallis testi kullanıldı. 
Tablo 2. Akciğer, Meme ve Kolon kanserlerine ve kontrol grubuna ait oksidatif stres parametrelerinin sonuçları.

\begin{tabular}{|c|c|c|c|c|c|}
\hline & $\begin{array}{l}\text { Kontrol Grubu } \\
\text { (n:43) }\end{array}$ & $\begin{array}{c}\text { Akciğer Ca } \\
\text { (n:44) }\end{array}$ & $\begin{array}{c}\text { Meme Ca } \\
(\mathrm{n}: 37)\end{array}$ & $\begin{array}{c}\text { Kolon Ca } \\
(\mathrm{n}: 20)\end{array}$ & $p^{*}$ \\
\hline $\begin{array}{l}\text { TAS(mmol } \\
\text { TroloxEquiv/L) }\end{array}$ & $1,17 \pm 0,15$ & $2,92 \pm 0,12$ & $2,98 \pm 0,12$ & $3,021 \pm 0,16$ & $0,001^{\#+a}$ \\
\hline $\begin{array}{l}\mathrm{TOS}(\mu \mathrm{mol} \\
\mathrm{H}_{2} \mathrm{O}_{2} \text { Equiv/L) }\end{array}$ & $5,21 \pm 1,67$ & $5,66 \pm 1,52$ & $6,40 \pm 1,42$ & $5,71 \pm 1,5$ & $0,002^{+}$ \\
\hline $\begin{array}{l}\text { KATALAZ } \\
(I U / \mathrm{mL})\end{array}$ & $12,08 \pm 5,017$ & $16,76 \pm 6,14$ & $19,30 \pm 6,38$ & $19,41 \pm 52,19$ & $0,001^{\#+a}$ \\
\hline $\begin{array}{l}\text { MPO } \\
\text { (IU/mL) }\end{array}$ & $188,05 \pm 89,73$ & $264,26 \pm 88,37$ & $272,71 \pm 124,59$ & $251,13 \pm 96,87$ & $0,001^{\#+a}$ \\
\hline $\begin{array}{l}\text { OSi } \\
\text { (AU) }\end{array}$ & $0,442 \pm 0,116$ & $0,193 \pm 0,049$ & $0,217 \pm 0,043$ & $0,199 \pm 0,042$ & $0,001^{\#+\alpha}$ \\
\hline
\end{tabular}

Sonuçlar ortalama \pm standart sapma şeklinde ifade edilmiştir. * One way ANOVA testi kullanılmıştır.

\#: Akciğer Ca vs Kontrol, +: Meme Ca vs Kontrol, a: Kolon Ca vs Kontrol, AU: Arbitrary Unit

Oksidatif stres vücudun redoks durumundaki bir dengesizlikten kaynaklanır. Redoks durumu, biyolojik süreçleri başlatmak için sinyal yollarını aktive eden ROS seviyelerinde ufak bir artış içerirken, oksidatif stress ise, DNA, protein ya da lipidlere zarar veren yüksek ROS seviyeleri içerir. ROS'un normal hücrelerin ve kanser hücrelerinin çoğalmasındaki regülasyonu farklıdır. Kanser hücreleri, hücresel büyüme ve çoğalmayı sürdürebilmek için büyüme faktörü yollarını normal hücrelere göre daha çok aktive eder. Bu, kanser hücrelerinin bol miktarda besin almasını, stres yaşamasını ve sürekli çoğalmasını sağlar. Sonuç olarak, kanser hücrelerinin 'hiper metabolizması', mitokondriden ve endoplazmik retikulumdan ROS'un bol miktarda üretilmesine ve ek olarak ta NADPH oksidazların etkisinin artmasına neden olur (20). Kanser hücrelerinde, ROS üretiminin normalden yüksek olması, redoks dengesini korumak için eşit derecede antioksidan aktivitesi ile dengelenir (21).

Hücrede güçlü antioksidanlardan olan katalaz ve glutatyon peroksidaz (GSH-Px) primer enzimatik savunma sistemleridir. Hidrojen peroksit $\left(\mathrm{H}_{2} \mathrm{O}_{2}\right)$, katalaz ve GSH-Px tarafından su ve moleküler oksijene dönüştürülerek metabolize edilmektedir (22). Katalaz; değişik kanser çeşitlerinde ortaya çıkan oksidatif strese karşı savunmada antioksidan sistemin öncelikli bir enzimidir. Rajneesh ve ark.(23) meme kanserinde katalaz düzeyinin yükseldiğini bulmuşlardır. Bir diğer çalışmada Kaynar ve ark.(17) akciğer kanserli hastalarda antioksidan enzim aktivitelerini incelemiş ve eritrosit malondialdehidi, nitrik oksit, total glutatyon düzeylerini ve eritrosit süperoksit dismutaz, katalaz ve ksantin oksidaz aktivitelerini kontrol grubuna göre anlamlı derecede yüksek bulmuştur. Bu çalışma akciğer kanserli hastalarda artmış oksijen radikallerinin yol açtığı antioksidan defans sisteminde önemli değişiklikler olduğunu göstermiştir. Bizim çaIışmamızda da her üç kanser türünde de bir antioksidan olan katalaz enziminin kontrol grubuna göre anlamlı şekilde artmış olduğu bulundu.

Bu artış orta derecedeki bir oksidatif sterese karşı muhtemel bir antioksidan defans olarak izah edilebilir. Hücresel antioksidan sistemler ROS'u detoksifiye ederek zararı SInırlamaya yardımcı olurken bir kısım antioksidan sistemler de oksidan aracılı değişiklikleri tersine çevirerek etki eder. İşte bu orta derecede oksidatif sterese karşı hücrede antioksidan enzimlerin ekspresyonunu düzenleyen bir transkripsiyon faktörü olan Nükleer faktör-eritroid 2'ye bağlı faktör 2 (Nrf2) bulunmuştur (24). Orta decede oksidatif sterse karşı antioksidan defans sistemi Nrf2 / Keap 1 IARE yolağını kullanarak çalışır. Nrf2, genellikle sitozol içerisinde Keap-1 proteini ile kompleks halinde bulunur. Hafif oksidatif stres nedeniyle Nrf2 bu kompleksten salınır ve çekirdeğe taşınır. Taşınan Nrf2, Maf proteini ile yeni bir kompleks oluşturur ve DNA üzerindeki antioksidan yanit elementine (ARE) bağlanarak çeşitli antioksidan enzimlerinin transkripsiyonunu başlatır. Aktive edilen spesifik antioksidan enzimler arasında SOD, katalaz, GSH-redüktaz, Glutatyon peroksidaz ve faz II enzimleri vardır. Bu enzimlerin, antineoplastik etkilere neden olduğu düşünülmektedir (25).

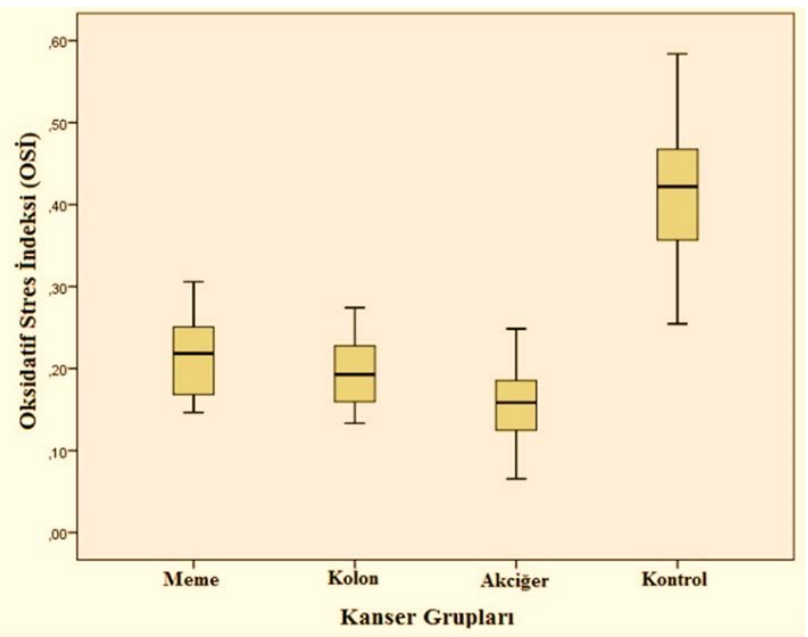

Şekil 1: Akciğer, Meme ve Kolon kanserlerine ve kontrol grubuna ait OSi değerleri.

Kutu grafikler ortalama \pm standart sapma şeklinde ifade edilmiştir. Kontrol grubu Osi değeri her üç kanser grubunun Osi değerinden anlamlı derecede yüksektir. $(p<0,001)$ 
Kronik inflamasyon, birçok başka hastalıkta olduğu gibi, neoplastik büyümede de kritik bir rol oynar. İnflamatuvar hücreler tarafından üretilen ROS'un, DNA mutasyonlarına yol açtığı ve kanser riskini arttırdığı öne sürülmüştür (26). Bu hücreler, miyeloperoksidaz (MPO) dahil olmak üzere enflamatuvar sitokinler ve okside edici ajanları serbest bırakır. MPO, nötrofiller ve makrofajlarda yüksek seviyelerde bulunur ve DNA'ya, proteinlere ve lipidlere zarar veren güçlü bir antimikrobiyal ve oksidan ajan olan hipokloröz asit $(\mathrm{HOCl})$ üretmek için hidrojen peroksit ile klor arasındaki reaksiyonu katalizler (27).

Artmış MPO ekspresyonun artmış malignite riski ile ilişkilendirilmesinde değişik mekanizmalar ortaya atılmıştır (28, 29). Bunlardan biri MPO'dan türetilen oksidanların, DNA'yı oluşturan DNA eklentilerine bağlanarak polisiklik aromatik hidrokarbonlar gibi kanserojenlerin biyolojik aktivasyonuna neden olmalarıdır. Bu onkogenlerde ve tümör süpresör genlerde mutasyonlara neden olabilir. MPO'nun diğer bir prokarsinojenik mekanizması, mutasyona uğramış hücrelerin çoğalmasına ve tümör büyümesinin artmasına yol açan apoptotik aktivitenin inhibisyonudur (29). Öte yandan hipokloröz asit te ayrıca DNA tamirinde güçlü bir inhibitör olarak bildirilmektedir.

Kanser dokularında yüksek MPO düzeylerinin saptanması karsinogenezdeki rolü ile uyumludur. Rainis ve ark. yaptıkları çalışmada kolorektal tümörlü hastaların mukozalarında kontrollerden daha fazla sayıda MPO pozitif hücre bulunduğu tespit etmişlerdir (30). Ayrıca evre II-IV over kanseri vakalarında da serum MPO düzeyleri daha yüksek bulunmuştur (31).

Myeloperoksidaz polimorfizmleri ve yanısıra immunohistokimya çalışmaları çok çeşitli malignitelerde kapsamlı olarak incelenmişstir. Akciğer kanseri, yumurtalık kanseri, meme kanseri, prostat kanseri, kolorektal kanser $(32,33)$ MPO ekspresyonuyla ilişkilendirilmiş malignitelerden bazılarıdır. Ancak serumda MPO düzeylerinin araştırılığı kanser türü neredeyse yok denecek kadar azdır.

Çalışmamızda her üç kanser türünde de serum MPO düzeylerini kontrol grubuna göre anlamlı şekilde yüksek bulmamız makrofajların azurofilik granüllerinde depolanan MPO'nun kanserde inflamasyona yanıt olarak hücre dışı sıvıya salınmasından kaynaklanıyor olabilir. Ayrıca kemoterapi sonrası görülen tümör lizis neticesinde hücre içi enzimin seruma dökülmesiyle de MPO'da artış yaşanmış olabilir. (34)

Çalışmamızın bazı sınırlamaları vardır. Bu çalışmanın çok merkezli, daha fazla sayıda ve hiç tedavi almamış hasta grubunda yapılması oksidatif stresin kanser türlerindeki düzeylerinin daha iyi belirlenmesini sağlayacaktır. Örneklem büyüklügü küçük olduğundan, bu sonuçları tüm kanser hastalarına genellemek zordur. Bir diğer sınırlama ise; Lipid hidroperoksit, SOD, glutatyon peroksidaz, glutatyon redüktaz ve tiyol düzeyleri gibi diğer oksidatif stres belirteçlerinin çalışımamış olmasıdır.
Sonuç olarak, bu çalışmada her üç kanser tipinde de oksidatif stresin arttığı ancak, artmış oksidatif stresin antioksidan savunma sistemini indüklemesi nedeni ile OSI seviyesini düşürmüş olabileceği bulundu. Ayrıca kanserde MPO düzeylerinin sağ|ıkı kişilere göre belirgin düzeyde yüksek olduğu bulundu. Ancak, bu sonuçları netleştirmek için daha kapsamlı ve kontrollü klinik çalışmalara intiyaç vardır.

\section{Kaynaklar}

1. Minna JD, Roth JA, Gazdar AF. Focus on lung cancer. Cancer cell. 2002;1(1):49-52.

2. Yılmaz I, Akçay MN, Polat MF, Demiryılmaz I, Biçer Ş. Kolorektal Kanserli Hastalarda Serum Paraoksonaz (PON) Seviyesi. Okmeydanı Tıp Dergisi. 2015;31(2):65-70.

3. Çiftçi N. Oksidatif Stresin Kanserdeki Rolü: Antioksidanlar Kanser Progresyonunun Yakıtı Olabilir mi? Ahi Evran Tıp Dergisi. 2017; 1: 8-13

4. Poirier LA. Stages in carcinogenesis: alteration by diet. Am J Clin Nutr 1987; 45:185-91.

5. Karabulut $H$, Gülay MŞ. Serbest radikaller. Mehmet Akif Ersoy Üniversitesi Sağllk Bilimleri Enstitüsü Dergisi. 2016;4(1).

6. Pham-Huy LA, He H, Pham-Huy C. Free radicals, antioxidants in disease and health. Int J Biomed Sci. 2008;4(2):89.

7. Halliwell B. Oxidative stress and neurodegeneration: where are we now? J Neurochem. 2006;97(6):1634-58.

8. Mittler R. ROS are good. Trends Plant Sci. 2017;22(1):11-9.

9. Erel O. A novel automated method to measure total antioxidant response against potent free radical reactions. Clin Biochem. 2004;37(2):112-9.

10. Erel $\mathrm{O}$. A new automated colorimetric method for measuring total oxidant status. Clin Biochem. 2005;38(12):1103-11.

11. Kavakli HS, Alici O, Koca C, Ihan A, Isik B. Caffeic acid phenethyl ester decreases oxidative stress index in blunt spinal cord injury in rats. Hong Kong J Emerg Me 2010;17(3):250.

12. Aebi HE. Methods of Enzymatic Analysis, H. U. Bergmeyer, ed., Third Edition, VCH, Weinheim, West Germany 1983;3:273.

13. Krawisz J, Sharon P, Stenson W. Quantitative assay for acute intestinal inflammation based on myeloperoxidase activity. Gastroenterology. 1984;87(6):1344-50.

14. Lobo V, Patil A, Phatak A, Chandra N. Free radicals, antioxidants and functional foods: Impact on human health. Pharmacogn Rev. 2010;4(8):118.

15. Birben E, Sahiner UM, Sackesen C, Erzurum S, Kalayci O. Oxidative stress and antioxidant defense. World Allergy Organ J. 2012;5(1):9.

16. Zabłocka-Słowińska K, Płaczkowska S, Skórska K, Prescha A, Pawełczyk K, Porębska I, et al. Oxidative stress in lung cancer patients is associated with altered serum markers of lipid metabolism. PLoS One 2019;14(4):e0215246.

17. Kaynar H, Meral M, Turhan H, Keles M, Celik G, Akcay F. Glutathione peroxidase, glutathione-S-transferase, catalase, xanthine oxidase, Cu-Zn superoxide dismutase activities, total glutathione, nitric oxide, and malondialdehyde levels in erythrocytes of patients with small cell and non-small cell lung cancer. Cancer Lett. 2005;227(2):133-9.

18. Gür T, Demir H, Kotan MÇ. Tumor markers and biochemical parameters in colon cancer patients before and after chemotherapy. Asian Pac J Cancer Prev. 2011;12(11):3147-50.

19. Ray G, Batra S, Shukla NK, Deo S, Raina V, Ashok S, et al. Lipid peroxidation, free radical production and antioxidant status in breast cancer. Breast Cancer Res Treat. 2000;59(2):163-70.

20. Cairns RA, Harris IS, Mak TW. Regulation of cancer cell metabolism. Nat Rev Cancer. 2011;11(2):85. 
21. Gorrini C, Harris IS, Mak TW. Modulation of oxidative stress as an anticancer strategy. Nat Rev Drug Discov. 2013;12(12):931.

22. Portakal O, Özkaya Ö, Bozan B, Koşan M, Sayek I. Coenzyme Q10 concentrations and antioxidant status in tissues of breast cancer patients. Clin Biochem. 2000;33(4):279-84.

23. Rajneesh CP, Manimaran A, Sasikala KR, Adaikappan P. Lipid peroxidation and antioxidant status in patients with breast cancer. Singapore Med J. 2008;49(8):640-3

24. Schumacker PT. Reactive oxygen species in cancer: a dance with the devil. Cancer Cell. 2015;27(2):156-7.

25. Sagai M, Bocci V. Mechanisms of action involved in ozone therapy: is healing induced via a mild oxidative stress? Med Gas Res. 2011;1(1):29.

26. Berasain C, Castillo J, Perugorria MJ, Latasa MU, Prieto J, Avila MA. Inflammation and liver cancer: new molecular links. Ann N Y Acad Sci. 2009;1155:206-21.

27. Engels EA. Inflammation in the development of lung cancer: epidemiological evidence. Expert Rev Anticancer Ther. 2008;8(4):605-15.

28. Ajila V, Ravi V, Kumari S, Babu S, Hegde S, Madiyal A. Serum and salivary myeloperoxidase in oral squamous cell carcinoma: $\mathrm{A}$ preliminary study. Clin Cancer Investig J. 2015;4(3):344.

29. Lai W-M, Chen C-C, Lee J-H, Chen C-J, Wang J-S, Hou Y-Y, et al. Second primary tumors and myeloperoxidase expression in buccal mucosal squamous cell carcinoma. Oral Surg Oral Med Oral Pathol Oral Radiol. 2013;116(4):464-73.

30. Rainis T, Maor I, Lanir A, Shnizer S, Lavy A. Enhanced oxidative stress and leucocyte activation in neoplastic tissues of the colon. Dig Dis Sci. 2007;52(2):526-30.

31. Castillo-Tong DC, Pils D, Heinze G, Braicu I, Sehouli J, Reinthaller A, et al. Association of myeloperoxidase with ovarian cancer. Tumor Biol. 2014;35(1):141-8.

32. Qin X, Deng Y, Zeng Z-Y, Peng Q-L, Huang X-L, Mo C-J, et al. Myeloperoxidase polymorphism, menopausal status, and breast cancer risk: an update meta-analysis. Plos One. 2013;8(8):e72583.

33. Arslan S, Pinarbasi H, Silig Y. Myeloperoxidase G-463A polymorphism and risk of lung and prostate cancer in a Turkish population. Mol Med Rep. 2011;4(1):87-92.

34. Aslam HM, Zhi C, Wallach SL. Tumor Lysis Syndrome: A Rare Complication of Chemotherapy for Metastatic Breast Cancer. Cureus. 2019;11(2):e4024 